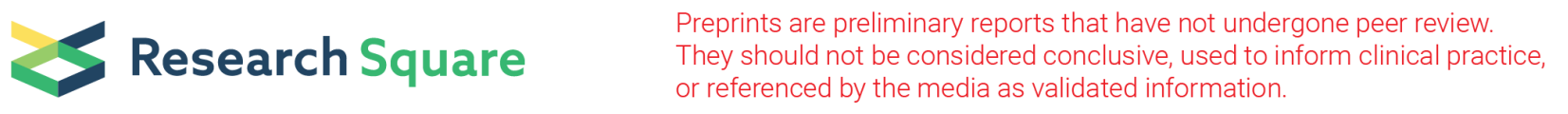

\title{
Reusing of Real Textile Wastewater After Treatment by Gamma Irradiation: Implications on the Growth of Capsicum Frutescens Plant
}

MD ARIFUL AHSAN ( $\nabla$ arifulahsan634@gmail.com )

Institute of Nuclear Science and Technology https://orcid.org/0000-0001-7228-5314

M. Safiur Rahman

Atomic Energy Centre

Md. Abdul Quaiyum Bhuiyan

Institute of Nuclear Science and Technology

Md. Saifur Rahaman

Institute of Nuclear Science and Technology

Mir Tamzid Rahman

Jahangirnagar University Faculty of Mathematical and Physical Sciences

Mubarak Ahmad Khan

Bangladesh Atomic Energy Commission

\section{Research Article}

Keywords: Textile wastewater treatment, Gamma Radiation, Wastewater reuse, Capsicum frutescens, Plant growth

Posted Date: August 18th, 2021

DOI: https://doi.org/10.21203/rs.3.rs-756207/v1

License: () (i) This work is licensed under a Creative Commons Attribution 4.0 International License. Read Full License 


\section{Abstract}

This investigation concentrates on the possibility of using gamma radiation for the decomposition of textile wastewater and reuse as irrigation water. The real wastewater sample was irradiated at four different radiation doses of 3, 5, 8, and $10 \mathrm{kGy}$. After irradiation at 8-10 KGy, physicochemical parameters, i.e., pH, turbidity, EC, total suspended solids (TSS), total dissolved solids (TDS), biological oxygen demand $\left(\mathrm{BOD}_{5}\right)$, and chemical oxygen demand $(\mathrm{COD})$ have decreased sharply and approached to the expected value. At maximum $10 \mathrm{KGy}$ radiation dose, $59.0 \% \mathrm{BOD}_{5}$ and $71.6 \% \mathrm{COD}$ removal have been achieved, accelerating the enhancement in biodegradability index $\left(\mathrm{BOD}_{5} / \mathrm{COD}, 0.43\right)$. Ammonium and total nitrogen have improved up to $87.0 \%$ and $94.5 \%$ after irradiation at 10 KGy doses. These treated textile wastewater samples were reused to grow Capsicum frutescens plants to inspect the fertility responses. When Capsicum plants were nourished by textile wastewater irradiated at 8-10 kGy, the dry masses of the fruits, moisture content, root length, average plant height, average number of leaves, and total number of fruits were increased in comparison to those plants nourished by simply water and raw wastewater. The elemental analysis confirmed that the heavy metals concentration in Capsicum fruits decreased gradually with higher radiation doses. Helpful macro and micronutrients for plant production such as $\mathrm{Na}, \mathrm{K}$, and $\mathrm{Mg}$ were raised at a sufficient level of $47.7 \%, 23.5 \%$, and $63.8 \%$ for $10 \mathrm{KGy}$, whereas the highest $50.0 \%$ increase in Ca concentration was found for 8 KGy fruit samples.

\section{Introduction}

Like many other developing countries, textile industries play an integral role in creating economic development in Bangladesh (Masum 2016). Massive amounts of dyes have been produced to fulfill the annual requirements of these different textile industries (Lourenço et al. 2001). In the market, nearly 10,000 variations of synthetic dyes are found, whereas more than 700,000 tons are generated per annum all over the world. Almost 200,000 tons of synthetic dyes are absorbed yearly due to the incompetent dyeing operation in most textile industries. It has been reported by the World Bank that around $17-20 \%$ of wastewater is produced from the textile finishing and dyeing treatment (Holkar et al. 2016; Ribeiro et al. 2017; Hossain et al. 2018). Although these textile industries generate significant economic profits, it also creates adverse environmental and social impacts by producing contaminated wastewaters from their complex processing operations (Al-Mamun et al. 2019). Textile industries are principal sources of discharging wastewaters, which are extensively colored, highly alkaline, and contain refractory organic materials (Noman et al. 2013). The activity of indiscriminate discharging of wastewater promotes a varying degree of pollution loads in water, soil and air. Almost in all environments, industrial wastes act as a leading source of pollution, posing esthetic pollution, eutrophication, and perturbations in aquatic life (Gemeay et al. 2003) because of their non-biodegradability, toxicity, carcinogenic, mutagenic natures (Mahmoodi and Arami 2010; Amini et al. 2011). These pollutants lead to excessive suspended solids (SS), chemical oxygen demand (COD), color intensity, acidity, and basicity exerting severe environmental problems. Industrial effluents adversely affect the soil ecosystems worldwide, resulting in health threats via the food cycle (Dahmani-Muller et al. 2001; Şolpan et al. 2003). The existence of dyes and their byproducts in water can cause severe human health threats such as nausea, headache, skin irritation, hemorrhage, and can also cause extreme damage to the kidney, brain, liver, central nervous system and reproductive system (Şolpan et al. 2003; Akpor and Muchie 2011; Ho et al. 2012).

As a solution to this problem, industrial effluents require treatment in situ before discharging into the environment (Emongor et al. 2005). Existing conventional methods like physical or chemical treatments cannot destroy the poisonous organic pollutants; instead, contaminants are transferred from an aqueous to a solid phase by the chemical coagulation method (Rabby 2011). Thus, extensive sludge is generated from the coagulation process, creating secondary pollution if not properly handled (Al-Mamun et al. 2019). Several researchers have followed the adsorption techniques (Panda et al. 2009; Islam et al. 2013), although these techniques are lengthy, unable to generate a waste-free clear solution, and are not cost-effective. Reversely, biological processes are usually simple, environment friendly having economic benefits, and often used to remove toxic waste from textile wastewater (Kim et al. 2004; AlMamun et al. 2019). However, typical biological methods (e.g., activated sludge process) cannot eradicate these organic pollutants rapidly due to their large size, complex molecular structure, and chemical nature that converts them as non-biodegradable in the environment (Kim et al. 2004). Advanced oxidation processes (AOPs) are also used to destroy wastewater dyes effectively, but their operation and maintenance costs are too high (Al-Mamun et al. 2019; Johnson et al. 2019). In this case, the application of gamma radiation, also known as ionizing radiation, can be used as a remedy for textile wastewater treatment as this is more powerful, economical, and environmentally favorable. Moreover, this treatment process gives some additional benefits such as no extra usage of chemicals, no residual or sludge generation, high penetration capability in various matrixes of water, and also unresponsive towards the insoluble solids that existed in wastewater (Guin et al. 2014; Parvin et al. 2015; Changotra et al. 2018, 2019). The main advantages of radiation treatment over the conventional methods prescribe that this method is adaptable because of its easy management in a unit

Page 2/18 
system as pollutants are destroyed by a rapid reaction mechanism and its capability of the simultaneous killing of pathogenic microorganisms along with destroying pollutants (Borrely et al. 1998).

Gamma radiation is one type of ionizing radiation with adequate energy to displace electrons from atoms and molecules, transforming them into electrically charged particles named ions (Selambakkannu et al. 2011). When gamma radiation is applied to the textile wastewater, radiolysis occurs in the water, producing excited and ionized water molecules with free electrons, highly reactive species. The application of gamma radiation is highly effective in aqueous solutions because the dye molecules found in the wastewater solution become degraded by the operation of primary products $\left(\cdot \mathrm{OH}, \mathrm{e}_{\mathrm{aq}}^{-} \mathrm{H}^{+}, \cdot \mathrm{H}, \mathrm{H}_{2} \mathrm{O}_{2}\right.$ ) produced by water radiolysis (Solpan 2002; Wang et al. 2006; Selambakkannu et al. 2011; Bhuiyan et al. 2015). Mainly the destruction of the conjugated system ( $\mathrm{N}=\mathrm{N}$ bonds) of the dye compounds occurs by the action of highly responsive hydroxyl radicals $(\cdot \mathrm{OH})$ (Sumartono 2008). Also, rapid addition occurs of this reactive species $(\cdot \mathrm{OH})$ to the unsaturated bonds of the benzene ring, which ultimately leads to the disintegration of aromatic rings and generates acetaldehyde, carboxylic acids with other species into the solution (Wojnarovits and Takacs 2008, 2013; Wang and Chu 2016). Because of the radiation effect, the longer organic chain degrades into shorter chains, which are adjoining to the major dye or azo groups (Nickelsen et al. 1992).

Nowadays, scientists worldwide have given their attention to reusing textile wastewater because of the increasing pollution in the water bodies and groundwater depletion created by the textile industries (Bhuiyan et al. 2015). The wastewater can be recycled as irrigation water into the agricultural sector because it contains several amounts of inorganic and organic nutrients, which can input a handsome amount of minerals for healthier crop production (Jolly et al. 2009). A few studies have reported applying gamma-rays to use actual textile wastewater treatment (Şolpan and Güven 2002; Bhuiyan et al. 2014a, 2015; Parvin et al. 2015). But unfortunately, very few studies have been conducted on treating industrial wastewater on the growth and yield of the Capsicum frutescens plant. Capsicum frutescens has been consumed as a spice all over the world. The fruits of Capsicum frutescens have a high content of ascorbic acid (Kumar and Tata 2009). Its leaves and fruit extracts have antifungal, antibacterial, antioxidant, anti-inflammatory, and anthelmintic activities (Soumya and Bindu 2012; Patricia et al. 2013). Also, it has a remarkable inhibitory effect on Plasma glucose (Chaiyata et al. 2003). However, our previous work on the growth and yield of vegetable spleen amaranth by applying irradiated wastewater (Parvin et al. 2015) is the driving force for this present study on Capsicum frutescens. The specific objectives for this work are (i) application of irradiation technology to disintegrate the dye compounds and organic pollutants as well as to increase the biodegradability $\left(\mathrm{BOD}_{5} / \mathrm{COD}\right.$ ratio) of the textile wastewater, (ii) to investigate the changes of physicochemical parameters and level of heavy metals of the irradiated textile wastewater, (iii) doses optimization of gamma irradiation for the treatment of the textile wastewater by applying different irradiation doses ranging from $3 \mathrm{KGy}$ to $10 \mathrm{KGy}$, (iv) to explore the recycling suitability of gamma-irradiated textile wastewater by applying into the vegetable species Capsicum frutescens and observing the growth rate and production effects of the plants and Capsicum fruits.

\section{Materials And Methods}

\section{Sample collection and gamma irradiation}

The combined actual textile wastewater samples were collected from the wastewater collection vessel from a knit dyeing textile industry, namely "Radial International Ltd.-Radiance Group" at Zirani Bazar, Kashimpur, Gazipur, Bangladesh. The samples were a composition of natural wastewater generated from different actions such as knitting, washing, and dyeing. The wastewater samples were gathered and sealed tightly in a $100 \mathrm{~L}$ clean and dry HDPE container and then sent for irradiation by gamma rays from the Cobalt60 gamma source of the Institute of Radiation and Polymer Technology (IRPT), Atomic Energy Research Establishment, Savar, Dhaka, Bangladesh. The gamma radiation source was in batch irradiation mode, and the combined textile wastewater was irradiated at various radiation doses $(3,5,8,10 \mathrm{kGy})$ at a dose rate of $13 \mathrm{kGy} / \mathrm{h}$. An Amber Perpex dosimeter (type 3042F) has been used to measure the given dose values throughout the irradiation process.

\section{Physicochemical analysis of raw and irradiated wastewater}

The textile wastewater samples (both treated and untreated) were subjected to physical and chemical characterization, i.e., pH, turbidity, TSS, TDS, EC, DO, BOD 5 and COD, to determine the optimum dose for decontamination. $\mathrm{pH}$, TDS, and EC for irradiated and unirradiated samples were determined using a portable Multimeter (Model no. sension ${ }^{\mathrm{TM}} 156, \mathrm{HACH}, \mathrm{USA}, 2000$ ) not over 30 minutes of the sample collection. The DO meter HQ40d from HACH, USA, was used to determine the DO values. BOD 5 of the wastewater samples were analyzed by five days $\mathrm{BOD}_{5}$ test at $20^{\circ} \mathrm{C}$ operating HACH DBR200 system following the standard procedures (APHA 2017). A single 
beam UV-spectrophotometric system, model: DR/4000U, HACH International, Colorado, USA, with the help of reactor digestion method, was used to measure the COD values. The turbidity was measured by portable turbidity meter WTW TURB 350 IR. An oven dried ( 30 min at $103-105^{\circ} \mathrm{C}$ ) fiber pad filter paper was weighed by analytical balance after cooling in desiccators for TSS measurement. Then 1000 $\mathrm{mL}$ samples were thoroughly shaken and filtered through the filter paper, followed by drying of the filter paper in the oven (30 min at $103-105^{\circ} \mathrm{C}$ ), cooling in the desiccators, and then take the dry weight of the materials (Bhuiyan et al. 2015). The total nitrogen and ammonium $\left(\mathrm{NH}_{4}{ }^{+}\right)$concentration of the treated and raw wastewater samples were also measured by the Kjeldahl and Kjeldahl distillation techniques (Mulvaney 1996).

\section{Experiments for the fertilizing effects by reusing of irradiated textile wastewater}

Tabasco peppers (Capsicum frutescens) plants were irrigated three times a week by the irradiated and unirradiated wastewater to inspect the scope of reusing of gamma-ray irradiated textile wastewater as irrigation water and its fertility impact. Twelve pots had prepared with twelve Capsicum plants (six types - two plants per type), where the plants were periodically fed by freshwater (control sample), unirradiated and irradiated $(3,5,8,10 \mathrm{kGy})$ textile wastewater. All the pots were kept under a transparent shed to avoid any further mixing with rainwater. Garden soil with good moisture content had used to prepare the pots. Every week the plants were checked before assessing the plant height, the number of leaves and fruits to correlate the consequence of irradiated textile wastewater with the unirradiated and freshwater. For evaluating the growth and yield, plant height was estimated from margin of the pot to the peak of the central plant stem. For determining the number of leaves, every apparent leaf of each plant was considered, including the emerging tips of fresh leaves (Bhuiyan et al. 2015; Parvin et al. 2015). Every single apparent Capsicum fruit was also counted to measure the number of fruits of each plant. All the plants were harvested on the $64^{\text {th }}$ day after implantation, and root lengths were measured. Capsicum fruits were collected from every plant and the total weight of fruits $\left(M_{\text {initial }}\right)$ was calculated. Then the fruits were dehydrated in the microwave oven at $105^{\circ} \mathrm{C}$ for 12 hours (Mollah et al. 2009). After weight loss, the samples were collected from the oven, allowed to cool down in the desiccators, and after that weighed and recorded as dry mass $\left(M_{d}\right)$. Eq. (1) was used to figure out the moisture content (\% MC) of the fruit samples (deMan et al. 2018).

$$
M C(\%)=\frac{M_{\text {initiat }}-M_{d d}}{M_{\text {initial }}} \times 100
$$

Here, $M_{\text {initial }}$ and $M_{d}$ were the mass of the fruit samples before and after drying, respectively.

\section{Elemental analysis of textile wastewater, soil, and Capsicum fruits}

A suitable volume of wastewater samples (both irradiated and unirradiated) was taken for the elemental analysis, filtered through Whatman 42 filter paper and then acidified by concentrated $\mathrm{HNO}_{3}$ until the $\mathrm{pH} \sim 2$. After that, $100 \mathrm{ml}$ of samples with $5 \mathrm{ml}$ concentrated $\mathrm{HNO}_{3}$ were taken and digested in a sealed chamber for 30 minutes. The end volume of samples was fixed up to $100 \mathrm{ml}$ with distilled water (APHA 2017). The harvested fruit (Capsicum frutescens) samples were washed with distilled water to clean the unwanted dust particles and soil. The samples were then air-dried and collected into fresh polyethylene bags, sealed, and kept in the refrigerator. Subsequently, the solid samples (soil and fruits) were dried in the oven at $103-105^{\circ} \mathrm{C}$ for 12 hours and ground into fine dust ( 80 mesh size) utilizing a mortar for microwave digestion (Mollah et al. 2009; Parvin et al. 2015). After that, $0.3 \mathrm{~g}$ of each plant and soil samples were weighed into the XP-1500 digestion vessel with $3 \mathrm{~mL} \mathrm{HNO} 3$ (Conc.) acid for digestion in Microwave Accelerated Reaction System (MARS 5, CEM Corporation, USA). After completion of digestion, the concluding volume of the sample solutions was fixed up to $10 \mathrm{ml}$ with distilled water. Digested wastewater and solid samples were then analyzed for metal concentrations by Atomic Absorption Spectrophotometer (Flame AAS, Varian AA240FS) and mercury (Hg) by cold vapor AAS (novAA350, Analytik Jena, Germany).

\section{Results And Discussions}

\section{Effect of irradiation on physicochemical parameters in textile wastewater}

The changes of physicochemical parameters for raw/unirradiated and irradiated wastewater are shown in Table 1. The main features of this textile wastewater were high pH, EC, TDS and TSS values with poor DO value. Similar values were also reported by Parvin et al. (2015) and comparatively lower values of pH, EC, TDS and TSS were found by Bhuiyan et al. (2015). The two-way ANOVA test ( $a=$ $0.05, p<0.017)$ also revealed that the physicochemical parameters ( $\mathrm{pH}$, Turbidity, EC, TDS and TSS) were significantly reduced $\left(F_{c a l}>\right.$ $\left.F_{\text {critic }}=3.12>2.6 ; d f=54 ; p=0.002\right)$ at a $95 \%$ confidence level (Table 2), which is consistent with the Pearson's correlation analysis 
(Table 3). The Pearson's correlation analysis showed that $\mathrm{pH}$ has strong positive correlation with turbidity $(r=0.984, p=0.002), \mathrm{EC}(r=$ $0.0 .992, p=0.001)$, TDS $(r=0.990, p=0.001)$, TSS $(r=0.985, p=0.002), \operatorname{BOD}(r=0.997, p=0.000), \operatorname{COD}(r=0.997, p=0.002)$ and nitrate $(r=0.984, p=0.002)$, while negative correlation was observed with DO $(r=-0.996, p<0.001)$, nitrogen $(r=-0.971, p=0.006)$ and ammonium $(r=-0.992, p=0.001)$. Therefore, it has been suggested that when $\mathrm{pH}$ values were reduced, at the same time turbidity, EC, TDS, TSS, BOD, COD and $\mathrm{NO}_{3}$ also reduced with the increasing of irradiation doses. Reversely, when pH values in wastewater were reduced, the values for DO, nitrogen (total) and ammonium were increased.

This study revealed that the $\mathrm{pH}$ values in the textile wastewater were gradually decreased with the rise of the irradiation doses from 3 to $10 \mathrm{KGy}$. At an irradiation dose of $10 \mathrm{KGy}$, the $\mathrm{pH}$ value in wastewater was found to be 8.19, which was enough for reuse as irrigation water since it satisfied the standard range of irrigation water (DoE 1997). It could happen because the application of gamma radiation oxidizes the more significant aromatic compounds that exist in the wastewater and generates mono and dicarboxylic acids or carbonic acid. Eventually, that forms carbon dioxide by further oxidation and lowers the pH value of the wastewater (Paul et al. 2011; Parvin et al. 2015; Bhuiyan et al. 2015).

The turbidity values for the textile wastewater samples were observed to reduce from 167.22-116.68 FTU. But the decreasing amount was almost similar for the doses of $8 \mathrm{KGy}(118.56 \mathrm{FTU})$ and $10 \mathrm{kGy}(116.68 \mathrm{FTU})$, having no such visible or analytical changes of turbidity within these doses (Table 1). The reduction in turbidity is, in fact, for the decrease in suspended particulate matter. Still, the practical logic is the destruction of larger organic dye molecules and the production of more minor colorless organic species by applying gamma radiation (Bagyo et al. 1997; Soutsas et al. 2010). The dissolved oxygen (DO) of the unirradiated wastewater was found only $0.3 \mathrm{mg} / \mathrm{L}$ (Table 1). Nevertheless, after gamma irradiation, it had increased to the standard value of 4.5-8 ppm for irrigation water (DoE 1997). The DO value gradually increased from unirradiated to irradiated textile wastewater but at a slower rate at the end. It might have occurred because of the demolition of larger molecules, the decrease in turbidity (Table 1) of the wastewater samples, along with the existence of radiolysis products of water $\left(\mathrm{O}_{2}, \mathrm{H}_{2} \mathrm{O}_{2}\right.$, etc.) due to gamma irradiation (Miyata 1993).

At $10 \mathrm{KGy}$ radiation dose, the EC value became $1690 \mu \mathrm{S} / \mathrm{cm}$, which was comparatively lesser than the EC value found in raw wastewater $(4010 \mu \mathrm{S} / \mathrm{cm})$ but not close to the standard value $(1200 \mu \mathrm{S} / \mathrm{cm})$ for irrigation water (DoE 1997). However, higher radiation doses were required to reduce the EC value because of ionized constitutes in the wastewater. $\mathrm{EC}$ has an approximate correlation with TDS (Rouse 1979), which was consistent with our Pearson's correlation data between EC and TDS (Table 3) having a strong positive correlation $(r=0.992, p<0.005, a=0.01)$. This study has been suggested that with the increment of irradiation dose, both EC and TDS values reduced significantly. A similar reduction tendency was also found for TDS (Table 1), which was $1540 \mathrm{mg} / \mathrm{L}$ at $10 \mathrm{KGy}$, lower than the recommended value of $2100 \mathrm{mg} / \mathrm{L}$ for irrigation quality of the water (DoE 1997). The suspended solids content of the wastewater readily lowered after the gamma-ray irradiation (Table 1). The TSS value was $486 \mathrm{mg} / \mathrm{L}$ for unirradiated wastewater and $217 \mathrm{mg} / \mathrm{L}$ for $10 \mathrm{KGy}$ radiation dose, almost near to the standard TSS value (200 mg/L) for irrigation water as per DoE (1997). There are two probable causes of TDS and TSS reduction; the first is the deterioration of suspended dye molecules persuaded through the reaction with oxidative agents from hydrolysis of water (Getoff 1996; Somasiri et al. 2006). The second cause is the destruction of bigger organic molecules into tinier ones by radiation (Nickelsen et al. 1992).

Table 1 Change of Physicochemical parameters of the irradiated and unirradiated samples of textile wastewater.

\section{Parameters Unit Raw / Unirradiated wastewater}

\begin{tabular}{|c|c|c|c|c|c|c|c|c|c|}
\hline & & & & & & \\
\hline & & $\begin{array}{l}\text { This } \\
\text { Study }\end{array}$ & $\begin{array}{l}\text { Bhuiyan et } \\
\text { al. (2015) }\end{array}$ & $\begin{array}{l}\text { Parvin et } \\
\text { al. (2015) }\end{array}$ & & 3 KGy & $5 \mathrm{KGy}$ & 8 KGy & $\begin{array}{l}10 \\
\text { KGy }\end{array}$ \\
\hline $\mathrm{pH}$ & - & 10.48 & 8.3 & 10.33 & $6.0-9.0$ & 9.72 & 9.18 & 8.64 & 8.19 \\
\hline Turbidity & FTU & 167.22 & - & 161.65 & - & 153.83 & 139.29 & 118.56 & 116.68 \\
\hline EC & $\mu S / \mathrm{cm}$ & 4010 & 2000 & 4140 & 1200 & 3640 & 2980 & 2160 & 1690 \\
\hline TDS & $\mathrm{mg} / \mathrm{L}$ & 3346 & 1050 & 3410 & 2100 & 2752 & 2460 & 1725 & 1540 \\
\hline TSS & $\mathrm{mg} / \mathrm{L}$ & 486 & 310 & 440 & 200 & 362 & 294 & 245 & 217 \\
\hline DO & $\mathrm{mg} / \mathrm{L}$ & 0.3 & - & 0.5 & $4.5-8.0$ & 2.4 & 3.8 & 4.9 & 5.7 \\
\hline
\end{tabular}


In the case of biological oxygen demand $\left(\mathrm{BOD}_{5}\right)$ and chemical oxygen demand $(\mathrm{COD})$, a notable reduction in $\mathrm{BOD}_{5}$ and $\mathrm{COD}$ values of the wastewater is observed with increasing radiation doses (Fig. 1). The recommended standard limit of $\mathrm{BOD}_{5}$ and $\mathrm{COD}$ for irrigation water is $100 \mathrm{mg} / \mathrm{L}$ and $400 \mathrm{mg} / \mathrm{L}$, respectively set by DoE (1997) which were duly achieved for the wastewater irradiated at 8-10 KGy in this study. The present study also revealed that at the highest radiation dose of $10 \mathrm{KGy}, 59.0 \%$ and $71.6 \%$ of BOD 5 and COD removal were obtained. A strong positive correlation $(r=0.992, p<0.005, a=0.01)$ between $\mathrm{BOD}_{5}$ and COD was observed (Table 3 ). It could happen because the reason that the ${ }^{\circ} \mathrm{OH}$ radicals are produced by the radiolysis of wastewater reacting with suspended solid materials and degrade the organic contaminants (Selambakkannu et al. 2011). As a result, the degradation of these organic pollutants also reduces the bulk of biodegradable matters in wastewater, which results in the lowering of $\mathrm{BOD}_{5}$ and COD values (Bhuiyan et al. 2015). The decline in COD values of the wastewater samples after radiation treatment could increase the biodegradability index $\left(B O D_{5} / C O D\right)$ ratio, which is evident from Fig. 1. However, the $\mathrm{BOD}_{5} / \mathrm{COD}$ ratio value elevated to 0.43 from 0.3 after irradiation. Also, $32.3 \%$ to $44.4 \%$ biodegradability of the wastewater samples increased after irradiation at 8-10 KGy (Fig. 1). For effective biological degradation of the wastewater biodegradability index $\left(\mathrm{BOD}_{5} / \mathrm{COD}\right)$ ratio value should be a minimum of 0.4 or higher (Symons et al. 1960; Al-Momani et al. 2002). In the present study, wastewater samples obtained biodegradability at 8-10 KGy radiation doses because at these doses $\mathrm{BOD}_{5} / \mathrm{COD}$ ratio was $0.4-0.43$ (Fig. 1 ).

Table 2 Two ways ANOVA for effect of radiation dose on changes of different physicochemical parameters.

\begin{tabular}{lllllll} 
Source of Variation & SS & $\boldsymbol{d f}$ & $\boldsymbol{M S}$ & $\boldsymbol{F}$ & $\boldsymbol{P}$-value & $\boldsymbol{F}$ crit \\
\hline Among variables & 53742748 & 10 & 5374275 & 42.52468 & $3.68 \mathrm{E}-18$ & 2.077248 \\
\hline Among doses & 1577631 & 4 & 394407.7 & 3.120805 & 0.025176 & 2.605975 \\
\hline Error & 5055205 & 40 & 126380.1 & & & \\
\hline Total & 60375585 & 54 & & & &
\end{tabular}

Table 3 Pearson correlation matrix of different physicochemical parameters in wastewater changing irradiation doses.

\begin{tabular}{|c|c|c|c|c|c|c|c|c|c|c|c|}
\hline & $\mathrm{pH}$ & Turbidity & EC & TDS & TSS & DO & BOD & COD & Nitrogen & Ammonia & Nitrate \\
\hline $\mathrm{pH}$ & 1 & & & & & & & & & & \\
\hline Turbidity & $.984^{\star \star}$ & 1 & & & & & & & & & \\
\hline EC & $.992 * \star$ & $.991^{\star \star}$ & 1 & & & & & & & & \\
\hline TDS & $.990 * \star$ & $.994 \star \star$ & $.992^{\star \star}$ & 1 & & & & & & & \\
\hline TSS & $.985^{\star \star}$ & $.966^{\star \star}$ & $.959 \star \star$ & $.968^{\star \star}$ & 1 & & & & & & \\
\hline DO & -.996 ** & $-.979 * \star$ & $-.979 * \star$ & $-.982^{\star *}$ & -.996 ** & 1 & & & & & \\
\hline BOD & $.997 \star \star$ & $.985^{\star \star}$ & $.997 \star \star$ & $.987^{\star \star}$ & $.970 \star \star$ & $-.987 \star \star$ & 1 & & & & \\
\hline COD & $.997 \star \star$ & $.991^{\star \star}$ & $.991^{\star \star}$ & $.996 \star \star$ & $.987 \star \star$ & $-.995^{\star \star}$ & $.992^{\star \star}$ & 1 & & & \\
\hline Nitrogen & -.971 ** & $-.970 * \star$ & $-.991^{\star *}$ & $-.973^{\star *}$ & $-.916^{\star}$ & $.947 *$ & $-.986 \star \star$ & $-.965^{\star \star}$ & 1 & & \\
\hline Ammonium & -.992 ** & $-.985^{\star \star}$ & $-.978 * \star$ & $-.982^{\star \star}$ & -.996 ** & $.998^{\star \star}$ & $-.984 \star \star$ & $-.994 * *$ & $.944^{\star}$ & 1 & \\
\hline Nitrate & $.978^{\star \star}$ & $.959 *$ & $.987 \star \star$ & $.973^{\star \star}$ & $.927 *$ & $-.955^{\star}$ & $.987^{\star \star}$ & $.969 * \star$ & $-.993^{\star *}$ & $-.945^{\star}$ & 1 \\
\hline
\end{tabular}

**. Correlation is significant at the 0.01 level (2-tailed).

*. Correlation is significant at the 0.05 level (2-tailed).

Effect of irradiation doses on total nitrogen and ammonium in textile wastewater 
This study revealed that the radiation treatment significantly improved the amount of total nitrogen $(\mathrm{N})$ and ammonium

$\left(\mathrm{NH}_{4}{ }^{+}\right)$contents in wastewater samples (Fig. 2). The unirradiated wastewater contained only $32.6 \mathrm{mg} / \mathrm{L}$ and $18.5 \mathrm{mg} / \mathrm{L}$ of total nitrogen and ammonium, but when the wastewater was irradiated at $10 \mathrm{KGy}$, total nitrogen and ammonia increased $63.4 \mathrm{mg} / \mathrm{L}$ and $34.6 \mathrm{mg} / \mathrm{L}$, respectively. However, the total nitrogen content increased $68.7 \%$ at $8 \mathrm{KGy}$ and $94.5 \%$ at $10 \mathrm{KGy}$. Again, $77.3 \%$ and $87.0 \%$ increase were observed for ammonium content in wastewater irradiated at $8 \mathrm{KGy}$ and $10 \mathrm{KGy}$, respectively (Fig. 2). The finding for applying irradiation dose on total nitrogen and ammonium in wastewater was completely reverse to changing of $\mathrm{pH}$ value, which can be seen in the Pearson's correlation data (Table 3). The Pearson's correlation revealed a strong negative correlation between $\mathrm{pH}$ and total nitrogen ( $r=$ $-0.971, p=0.006, a=0.01)$ and ammonium $(r=-0.992, p<0.005, a=0.01)$. As a consequence of applying radiation, the stubborn portions of the azo dyes in wastewater have degraded efficiently, and thus nitrogen molecules appeared into the solution immediately after digestion (Nicklesen et al. 1992; Somasiri et al. 2006; Parvin et al. 2015). Besides, gamma radiation converted the existing azo dyes in wastewater into amides, which were then modified into ammonia by hydrolysis and then as ammonium ion, an important source of plant fertilizer (Bagyo et al. 1997).

\section{Impact of irradiation doses on metals concentration in textile wastewater}

This present study observed that the analyzed raw and irradiated wastewater samples carried a lower concentration of heavy metals (Table 4). The textile industry from where the wastewater samples were collected mainly consumes reactive and disperse dyes for dyeing. Shore (2002) reported that metal complex groups are not found in disperse dyes, and reactive dyes contain only $12-15 \%$ of metal complex azo groups. Hence, it is expected to found a lower concentration of heavy metals in the studied wastewater samples. Heavy metals like $\mathrm{Cr}, \mathrm{Pb}, \mathrm{Ni}$, and $\mathrm{Cu}$ are crucial because of their bio-accumulation solid capability, which could harm humans when introduced into the food cycle (Fisseha 1998; Itanna 2002). Among the heavy metals Pb, $\mathrm{Cr}, \mathrm{Zn}, \mathrm{Co}, \mathrm{Ni}, \mathrm{Cu}, \mathrm{Mn}$, and Hg showed higher values in the wastewater samples irradiated at 3, 5, 8, and $10 \mathrm{KGy}$ doses than in unirradiated wastewater samples (Table 4). However, arsenic (As) and cadmium (Cd) were found less than the detection limit in elemental analysis. An increase in the metal contents in the irradiated wastewater may be due to the freeing of metals from trapped or chelating forms within the organic compounds that exist in the wastewater solution (Parvin et al. 2015). These obtained metal values were within the tolerable limits for using the wastewater as irrigation water (DoE 1997; Ayers and Westcot 1985; USEPA 2012). Only copper (Cu) and manganese (Mn) concentrations were higher, according to Ayers and Westcot (1985), but they were found well below the maximum allowable limit set by DoE (1997).

Table 4 Metal concentration (in $\mathrm{mg} / \mathrm{L}$ ) for raw and gamma irradiated textile wastewater. 


\begin{tabular}{|c|c|c|c|c|c|c|c|c|}
\hline \multirow[t]{2}{*}{ Metal Name } & \multirow[t]{2}{*}{$\begin{array}{l}\text { Raw wastewater (0 } \\
\text { KGy) }\end{array}$} & \multirow[t]{2}{*}{$3 \mathrm{KGy}$} & \multirow[t]{2}{*}{$5 \mathrm{KGy}$} & \multirow[t]{2}{*}{8 KGy } & \multirow[t]{2}{*}{10 KGy } & \multicolumn{3}{|c|}{$\begin{array}{l}\text { Standard for irrigation water }{ }^{a, b} \text {, } \\
{ }^{c}(\mathrm{mg} / \mathrm{L})\end{array}$} \\
\hline & & & & & & a & b & c \\
\hline Arsenic (As) & $<0.0003$ & $<0.0003$ & $<0.0003$ & $<0.0003$ & $<0.0003$ & 0.2 & 0.1 & 0.1 \\
\hline Cadmium (Cd) & $<0.004$ & $<0.004$ & $<0.004$ & $<0.004$ & $<0.004$ & 0.05 & 0.01 & 0.01 \\
\hline Calcium (Ca) & 0.2348 & 0.3562 & 0.3498 & 0.4028 & 0.3853 & - & - & - \\
\hline Chromium (Cr) & 0.0791 & 0.0827 & 0.0848 & 0.0965 & 0.0950 & 1 & 0.1 & 0.55 \\
\hline Cobalt (Co) & $<0.004$ & 0.0077 & 0.0080 & 0.0086 & 0.0089 & - & 0.05 & 0.05 \\
\hline Copper (Cu) & 0.0544 & 0.0630 & 0.0661 & 0.0863 & 0.0825 & 3 & 0.2 & 0.017 \\
\hline Iron (Fe) & 0.0099 & 0.0217 & 0.0190 & 0.0364 & 0.0383 & 2 & 5 & 0.5 \\
\hline Lead $(\mathrm{Pb})$ & 0.0317 & 0.0402 & 0.0446 & 0.0505 & 0.0527 & 0.1 & 5 & 0.065 \\
\hline $\begin{array}{l}\text { Magnesium } \\
(\mathrm{Mg})\end{array}$ & 0.0957 & 0.1883 & 0.1627 & 0.2199 & 0.2577 & - & - & - \\
\hline $\begin{array}{l}\text { Manganese } \\
(\mathrm{Mn})\end{array}$ & 0.1605 & 0.2484 & 0.2347 & 0.2775 & 0.2914 & 5 & 0.2 & 0.2 \\
\hline Mercury (Hg) & 0.0011 & 0.0012 & 0.0013 & 0.0015 & 0.0015 & 0.01 & - & - \\
\hline Nickel (Ni) & $<0.004$ & 0.0093 & 0.0103 & 0.0127 & 0.0133 & 1 & 0.2 & 1.4 \\
\hline Potassium (K) & 0.3752 & 0.7229 & 0.9294 & 1.1403 & 1.2546 & - & - & - \\
\hline Sodium $(\mathrm{Na})$ & 0.1938 & 0.6570 & 0.5860 & 0.8274 & 0.9483 & - & - & - \\
\hline Zinc (Zn) & 0.0120 & 0.0172 & 0.0166 & 0.0185 & 0.0188 & 10 & 2 & 0.2 \\
\hline \multicolumn{9}{|l|}{ a DoE (1997) } \\
\hline \multicolumn{9}{|l|}{ b USEPA (2012) } \\
\hline \multicolumn{9}{|c|}{ c Ayers and Westcot (1985); Itanna (2002); Chiroma et al. (2014) } \\
\hline \multicolumn{9}{|c|}{$\begin{array}{l}\text { Also, a higher concentration of potassium (K), sodium ( } \mathrm{Na} \text { ), calcium (Ca), magnesium (Mg), and iron (Fe) were found in the irradiated } \\
\text { wastewater than the unirradiated (Table 4), which could be helpful for plant growth as these are the vital micro and macronutrients for } \\
\text { plants (Begum et al. 2011; Bhuiyan et al. 2015). In addition, heavy metals analysis of the soil used for plant cultivation was presented } \\
\text { in Table 5. Almost all the heavy metal concentrations in the soil samples were within the maximum allowable limit (Ewers 1991; Itanna } \\
\text { 2002; Chiroma et al. 2014; WHO 2006). Moreover, the other metals like } \mathrm{Na}, \mathrm{Mg}, \mathrm{Ca} \text {, K, and Fe, essential for plant growth, were present in } \\
\text { an expected concentration that made the soil suitable for the experiments. }\end{array}$} \\
\hline
\end{tabular}

Table 5 Metal concentration $(\mathrm{mg} / \mathrm{kg})$ in soil for plant cultivation. 


\begin{tabular}{llll} 
Metal Name & Concentration $(\mathrm{mg} / \mathrm{kg})$ & \multicolumn{2}{c}{ Maximum Allowable limit ${ }^{\text {a, b }}(\mathrm{mg} / \mathbf{k g})$} \\
\cline { 3 - 4 } & & $\mathbf{a}$ & $\mathbf{b}$ \\
\hline Arsenic (As) & 1.33 & 20 & 8 \\
\hline Cadmium (Cd) & 0.55 & 3 & 4 \\
\hline Chromium (Cr) & 1.33 & 100 & - \\
\hline Calcium (Ca) & 0.55 & - & - \\
\hline Cobalt (Co) & 42.14 & 50 & - \\
\hline Copper (Cu) & 168.78 & 100 & - \\
\hline Iron (Fe) & 6.67 & 50000 & - \\
\hline Lead (Pb) & 18.26 & 100 & 84 \\
\hline Magnesium (Mg) & 34.46 & - & - \\
\hline Manganese (Mn) & 26.68 & 2000 & - \\
\hline Mercury (Hg) & 82.68 & - & - \\
\hline Nickel (Ni) & 126.22 & 50 & 107 \\
\hline Potassium (K) & $<0.003$ & - & - \\
\hline Sodium (Na) & 39.64 & - & - \\
\hline Zinc (Zn) & 142.84 & 300 & - \\
\hline
\end{tabular}

a Ewers (1991); Itanna (2002); Chiroma et al. (2014)

b WHO (2006)

\section{Impacts of reused irradiated textile wastewater on Capsicum plants and fruits}

In the present study, considerable changes were observed in plant morphologies for the Capsicum plants nourished by irradiated textile wastewater after 64 days of the experiment. Fig. 3 shows the variation in plant growth parameters such as average plant height ('cm' per week), the average number of leaves (per week), and root length up to 64 days (during harvesting) of Capsicum frutescens as a function of different radiation doses on textile wastewater including the unirradiated and control samples. The highest average plant height $(4.07 \mathrm{~cm})$ and most average number of leaves $(16 \mathrm{nos}$.) were found for the plants irrigated by $8 \mathrm{kGy}$ and $10 \mathrm{KGy}$ irradiated wastewater. Also, these morphological values of Capsicum plants nourished by only freshwater (control sample) and unirradiated wastewater were lower than the plant treated by gamma-ray irradiated (3-10 kGy) wastewater (Fig. 3). Identical results were also observed in the case of root length for the Capsicum plants. As presented in Fig. 3, the maximum root length of $16.56 \mathrm{~cm}$ was found for the plants irrigated by $8 \mathrm{kGy}$, whereas $13.21 \mathrm{~cm}$ and $8.33 \mathrm{~cm}$ root lengths were found for the control sample and Capsicum plants treated with unirradiated textile wastewater, respectively. Notable growth in plant morphologies and root lengths were found for the plants irrigated by irradiated wastewater, perhaps because of the absorption of nutrients from the irradiated wastewater enriched with organic wastes and increased nutrients such as K, Na, Mg, and Zn (Begum et al. 2011; Bhuiyan et al. 2015).

Evident effects were also found on the dry mass, moisture content (\%), fruit growing time, and the total number of fruits of Capsicum plants (Fig. 4) after implementing gamma-ray irradiated textile wastewater. The Capsicum fruits grew after 29 days on the plant nourished by wastewater radiated at $10 \mathrm{kGy}$. On the other hand, the plants fed with only water and raw wastewater, the fruits grew after 41 days and 59 days, respectively. Maximum 40 fruits and $3.02 \mathrm{~g}$ dry mass of these fruits were gained from the Capsicum plants treated by $8 \mathrm{kGy}$ gamma-irradiated textile wastewater. The dry mass for the control sample was $2.25 \mathrm{~g}$ (total 25 fruits), and the plants treated with raw textile wastewater were $0.17 \mathrm{~g}$ (total two fruits only). According to Fig. 4, the other plants treated with 3, 5, and 10 kGy gamma-ray irradiated textile wastewater showed a better result than the plants treated with only raw textile wastewater. Contrariwise, the highest moisture content (93.2\%) was found for the fruits collected from the plants treated with raw wastewater, and $92.62 \%$ moisture content was found for $8 \mathrm{KGy}$ fruit samples, which showed comparatively better performance among the irradiated and control 
fruit samples. Gamma irradiated textile wastewater possessed a higher concentration of nitrogen and ammonia, which ultimately influenced the increase in dry mass and moisture content of the Capsicum fruits (Parvin et al. 2015; Bhuiyan et al. 2015).

\section{Metals concentration in Capsicum fruits}

The analysis of Capsicum fruit samples for heavy metals concentration and the macro and micronutrients was done and presented in Fig. $\mathbf{5 a}$ and $\mathbf{5 b}$, respectively. The outcomes show that heavy metals concentration ( $\mathrm{Pb}, \mathrm{Cr}, \mathrm{Hg}, \mathrm{Ni}, \mathrm{Cu}$, and $\mathrm{Zn}$ ) in Capsicum fruits decreased progressively as higher doses of treated wastewater were implemented (Fig. 5a). The outcome indicates a distinguished translocation of these metals from the soil to the plant reproductive organs. At the highest radiation dose of $10 \mathrm{KGy}, \mathrm{Chromium}(\mathrm{Cr})$ and lead $(\mathrm{Pb})$ were found $0.04 \mathrm{mg} / \mathrm{kg}$ and $0.16 \mathrm{mg} / \mathrm{kg}$ for Capsicum fruit samples which were below the acceptable limit of $2.3 \mathrm{mg} / \mathrm{kg}$ and $0.3 \mathrm{mg} / \mathrm{kg}$, respectively (Itanna 2002; Codex FAO/WHO 2001; Chiroma et al. 2014). Whereas Nickel (Ni) and Mercury (Hg) in Capsicum fruit samples were found below the detection limit in elemental analysis, and $0.925 \mathrm{mg} / \mathrm{kg} \mathrm{Ni}$ was found only in the fruit samples irradiated by raw wastewater. Copper $(\mathrm{Cu})$ content was reported up to $0.016 \mathrm{mg} / \mathrm{kg}$ in the fruit samples nourished by $10 \mathrm{kGy}$ gammaray irradiated textile wastewater (Fig. 5a), which was exceedingly low compared to the highest permissible limit (73 mg/kg) of copper in vegetables (Itanna 2002; Codex FAO/WHO 2001; Chiroma et al. 2014). Zinc (Zn) concentration was 0.109 mg/kg in Capsicum fruit samples at $10 \mathrm{kGy}$, which was also insignificant against the maximum allowable limit of $100 \mathrm{mg} / \mathrm{kg}$ (Itanna 2002; Codex FAO/WHO 2001; Chiroma et al. 2014). Zn and Cu are essential nutrients for the plant that might be uptaken from the soil used for cultivation. The applied irradiated wastewater contains minor amounts of $\mathrm{Zn}$ and $\mathrm{Cu}$ than the soil (Table 4 \& 5).

Iron $(\mathrm{Fe})$ is one of the essential metals for human health. Still, the analytical result showed no Fe metal consumed by the Capsicum fruits, not even in the fruit samples nourished by only water and raw wastewater. The concentration of different nutrients such as sodium $(\mathrm{Na})$, potassium $(\mathrm{K})$, magnesium $(\mathrm{Mg})$, and calcium $(\mathrm{Ca})$, which are crucial for plant growth, found relatively more remarkable in the fruit samples of Capsicum plants cultivated by irradiated wastewater than the plants grown by only water and raw wastewater (Fig. 5b). Moreover, $\mathrm{Na}, \mathrm{K}$, and $\mathrm{Mg}$ had increased at a maximum level of $47.7 \%, 23.5 \%$ and $63.8 \%$, respectively, for $10 \mathrm{KGy}$ and the highest $50.0 \%$ rise in $\mathrm{Ca}$ concentration was found for $8 \mathrm{KGy}$ among all the fruit samples. Different organic complexes were present in the raw wastewater with nutrient elements as ligands that become degraded at higher doses of gamma radiation and released into the wastewater as free elements (Paul et al. 2011; Parvin et al. 2015; Bhuiyan et al. 2015). As a result, these free macro and micronutrients can be uptaken easily by the plants when applied to them (Parvin et al. 2015). Also, high nutrients level was found due to increased root lengths of the Capsicum plants irrigated by irradiated wastewater (Begum et al. 2011; Bhuiyan et al. 2015).

\section{Conclusion}

From this present comprehensive investigation, it has been observed that gamma radiation can efficiently break down the textile dyes and large organic contaminants in wastewater solutions which eventually reduce the pH, BOD, COD, turbidity, EC, TDS, and TSS of textile wastewater. Significant improvements have been noticed in DO, ammonium, and total nitrogen content. The decline in COD values has influenced the increase in the biodegradability index of irradiated wastewater. This outcome reveals an impressive sign of the irradiated textile wastewater that could have been recycled as irrigation water with fertilizing characteristics. After implementing gamma-ray irradiated textile wastewater, the growth and production rate of the Capsicum frutescens have been reinforced in contrast to that of the plants cherished with unirradiated wastewater and only water. According to the elemental analysis report, the heavy metals exist in negligible amounts, but vital macro and micronutrients for plant development and human wellness are obtained at a superior level in Capsicum fruits, indicating fascinating and fruitful results.

The outcome of this research will develop a convenient way of wastewater treatment and reusing irradiated wastewater for irrigation purposes by which environmental threats can be removed effectively. The physicochemical features of the irradiated wastewater, the plants' morphological characteristics, and the Capsicum fruits production approach to a decent level at the radiation doses of 8-10 KGy. So, irradiation of textile wastewater by gamma-ray at 8-10 KGy doses could be an alternative solution for wastewater treatment. Besides, due to having fertilizing properties of the treated wastewater, it can be reused as irrigation water, and the extra cost of fertilizer could have been reduced. Therefore, it has been suggested that textile wastewater can be converted into water resources by applying gamma radiation which may solve the existing and rising environmental problems.

\section{Declarations}


Acknowledgment The authors are grateful to the late M. Manzurul Karim, Professor of the Department of Chemistry, Jahangirnagar University, Savar, Dhaka, Bangladesh, for his continuous support and cordial help in the research work.

Conflicts of interest All the authors declare that there are no conflicts of interest in this research.

Funding No funds have been received for this research. The authors did this research by self-funding.

Availability of data and material All the authors declare that all the data and materials are available.

\section{References}

1. Akpor OB, Muchie M (2011) Environmental and public health implications of wastewater quality. Afr J Biotechnol 10(13):23792387.

2. Al-Mamun MR, Kader S, Islam MS, Khan MZH (2019) Photocatalytic activity improvement and application of UV-TiO 2 photocatalysis in textile wastewater treatment: a review. J Environ Chem Eng 7(5):103248. https://doi.org/10.1016/j.jece.2019.103248

3. Al-Momani F, Touraud E, Degorce-Dumas JR, Roussy J, Thomas O (2002) Biodegradility enhancement of textile dyes and textile wastewater by VUV photolysis. J Photochem Photobiol A: Chem 153(1-3):191-197. https://doi.org/10.1016/S10106030(02)00298-8.

4. APHA (2017) Standard Methods for the Examination of Water and Waste water, 23rd edn. American Public Health Association, Washington DC.

5. Amini M, Arami M, Mahmoodi NM, Akbari A (2011) Dye removal from colored textile wastewater using acrylic grafted nanomembrane. Desalination 267:107-113. https://doi.org/10.1016/j.desal.2010.09.014

6. Ayers RS, Westcot DW (1985) Water quality for agriculture. FAO Irrigation and Drainage paper. 29(1):01-120.

7. Bagyo AN, Arai H, Miyata T (1997) Radiation-induced decoloration and sedimentation of colloidal disperse dyes in water. Appl Radiat Isotopes 48(2):175-181. http://dx.doi.org/10.1016/S0969-8043(96)00182-0.

8. Begum R, Zaman M, Mondol A, Islam M, Hossain M (2011) Effects of textile industrial waste water and uptake of nutrients on the yield of rice. Bangladesh J Agric Res 36(2):319-331. http://dx.doi.org/10.3329/bjar.v36i2.9260.

9. Bhuiyan MR, Rahman MM, Shaid A, Bashar MM, Khan MA (2015) Scope of reusing and recycling the textile wastewater after treatment with gamma radiation. J Cleaner Prod 112(4):3063-3071. https://doi.org/10.1016/j.jclepro.2015.10.029

10. Bhuiyan MR, Rahman MM, Shaid A, Khan MA (2014a) Decolorization of textile wastewater by gamma irradiation and its reuse in dyeing process. Desalination Water Treat 54(10):2848-2855. http://dx.doi.org/10.1080/19443994.2014.905977

11. Bhuiyan MR, Shaid A, Hossain MA, Khan MA (2015) Decolorization and decontamination of textile wastewater by gamma irradiation in presence of $\mathrm{H}_{2} \mathrm{O}_{2}$. Desalination Water Treat 57(45):21545-21551. https://doi.org/10.1080/19443994.2015.1125804

12. Borrely SI, Cruz AC, Del Mastro NL, Sampa MHO, Somessari ES (1998) Radiation processing of sewage and sludge. A review. Prog Nucl Energ 33(1-2):3-21. https://doi.org/10.1016/S0149-1970(97)87287-3

13. Chaiyata P, Puttadechakum S, Komindr S (2003) Effect of Chili Pepper (Capsicum frutescens) ingestion on plasma glucose response and metabolic rate in Thai women. J Med Assoc Thai 86:854-860.

14. Changotra R, Guin JP, Dhir A, Varshney L (2018) Decomposition of antibiotic ornidazole by gamma irradiation in aqueous solution: kinetics and its removal mechanism. Environ Sci Pollut Res 25:32591-32602, https://doi.org/10.1007/s11356-018-3007-x.

15. Changotra R, Guin JP, Varshney L, Dhir A (2018) Assessment of reaction intermediates of gamma radiation-induced degradation of ofloxacin in aqueous solution. Chemosphere 208:606-613, https://doi.org/10.1016/J.CHEMOSPHERE.2018.06.003

16. Changotra R, Rajput H, Guin JP, Varshney L, Dhir A (2019) Hybrid coagulation, gamma irradiation and biological treatment of real pharmaceutical wastewater. Chem Eng J 370:595-605. https://doi.org/10.1016/j.cej.2019.03.256.

17. Chapman D (1992) Water Quality Assessment, Published on behalf of UNESCOA-VHOAJNEP. Chapman \& Hall, London, New York, Tokyo, Melbourne, Madras.

18. Chiroma TM, Ebewele RO, Hymore FK (2014) Comparative Assessment of Heavy Metal Levels in Soil, Vegetables and Urban Grey Waste Water Used for Irrigation in Yola and Kano. Int Ref J Eng Sci 3(2):01-09. 
19. Dahmani-Muller H, Van Oort F, Balabane M (2001) Metal extraction by Arabidopsis halleri grown on an unpolluted soil amended with various metal-bearing solids: a pot experiment. Environ Pollut 114(1):77-84. https://doi.org/10.1016/S0269-7491(00)00203-7

20. deMan JM, Finley JW, Hurst WJ, Lee CY (2018) Principles of Food Chemistry, Food Science Text Series, Appendix A: Moisture Analysis, Springer International Publishing AG, pp 567-607, https://doi.org/10.1007/978-3-319-63607-8

21. DoE (1997) The Environment Conservation Rules (E.C.R.). Bangladesh Department of Environment, Ministry of Environment and Forest, Government of the People's Republic of Bangladesh, pp 179-227.

22. Emongor V, Nkegbe E, Kealotswe B, Koorapetse I, Sankwasa S, Keikanetswe S (2005) Pollution Indicators in Gaborone Industrial Effluent. J Appl Sci 5(1):147-150. https://doi.org/10.3923/jas.2005.147.150

23. Ewers U (1991) Standards, guidelines, and legislative regulations concerning metals and their compounds. In: Merian E (ed) Metals and Their Compounds in the Environment: Occurrence, Analysis and Biological Relevance. Weinheim: VCH, pp 458-468.

24. FAO/WHO (2001) Codex Alimentarius Commission. Food additives and contaminants-joint FAO/WHO Food standards programme. ALINORM 01/12A, pp 01-289.

25. Fisseha I (1998) Metal concentrations of some vegetables grown with industrial liquid waste at Akaki, Ethiopia. SINET: Ethiop J Sci 21(1):49-57. https://doi.org/10.4314/sinet.v21i1.18116

26. Gemeay AH, Mansour IA, El-Sharkawy RG, Zaki AB (2003) Kinetics and mechanism of the heterogeneous catalyzed oxidative degradation of indigo carmine. J Mol Catal A Chem 193(1-2):109-120. https://doi.org/10.1016/S1381-1169(02)00477-6

27. Getoff N (1996) Radiation induced degradation of water pollutants-state of the art. Radiat Phys Chem 47(4):581-593. https://doi.org/10.1016/0969-806X(95)00059-7

28. Guin JP, Naik DB, Bhardwaj YK, Varshney L (2014) Studies on oxidative radiolysis of ibuprofen in presence of potassium persulfate. Radiat Phys Chem 100:38-44. https://doi.org/10.1016/J.RADPHYSCHEM.2014.03.016

29. Ho YC, Show KY, Guo XX, Norli I, Abbas FMA, Morad N (2012) Industrial Discharge and Their Effect to the Environment, Industrial Waste, Prof. Kuan-Yeow Show (ed), ISBN: 978-953-51-0253-3, Intech.

30. Holkar CR, Jadhav AJ, Pinjari DV, Mahamuni NM, Pandit AB (2016) A critical review on textile wastewater treatments: possible approaches. J Environ Manage 182:351-366. https://doi.org/10.1016/j.jenvman.2016.07.090

31. Hossain L, Sarker SK, Khan MS (2018) Evaluation of present and future wastewater impacts of textile dyeing industries in Bangladesh. Environ Dev 26:23-33. https://doi.org/10.1016/j.envdev.2018.03.005

32. Islam JMM, Habib SMA, Parvin F, Rahman MF, Saadat AHM, Khan MA (2013) Removal of industrial dye effluent (drimarene yellow) by renewable natural resources. Am Acad Scholar Res J 5:144-150.

33. Itanna F (2002) Metals in leafy vegetables grown in Addis Ababa and toxicological implications. Ethiop J Health Dev 16(3):295302. https://doi.org/10.4314/ejhd.v16i3.9797

34. Johnson I, Ali MAS, Kumar M (2019) Chapter 10 - Cyanobacteria/Microalgae for Distillery Wastewater Treatment- Past, Present and the Future. In: Shah MP, Rodriguez-Couto S (ed) Microbial Wastewater Treatment. Elsevier, pp 195-236.

https://doi.org/10.1016/B978-0-12-816809-7.00010-5

35. Jolly YN, Islam A, Mustafa A (2009) Characterization of dye industry effluent and assessment of its suitability for irrigation purpose. J Bangladesh Acad Sci 33(1):99-106. http://dx.doi.org/10.3329/jbas.v33i1.2954

36. Kim TH, Park C, Lee J, Shin EB, Kim S (2004) Comparison of disperse and reactive dye removals by chemical coagulation and Fenton oxidation. J Hazard Matter 112(1-2):95-103. https://doi.org/10.1016/j.jhazmat.2004.04.008

37. Kumar OA, Tata SS (2009) Ascorbic Acid Contents in Chili Peppers (Capsicum L.). Not Sci Biol 1(1):50-52.

38. László W, Takács E (2008) Irradiation treatment of azo dye containing wastewater: An overview. Radiat Phys Chem 77(3):225-244. https://doi.org/10.1016/j.radphyschem.2007.05.003

39. Lourenco ND, Novais JM, Pinheiro HM (2001) Effect of some operational parameters on textile dye biodegradation in a sequential batch reactor. J Biotechnol 89(2-3):163-174. https://doi.org/10.1016/S0168-1656(01)00313-3

40. Mahmoodi NM, Arami M (2010) Immobilized titanianano photocatalysis: degradation, modeling and toxicity reduction of agricultural pollutants. J Alloy Compd 506:155-159.

41. Masum M (2016) The Bangladesh textile-clothing industry: a demand-supply review. Social Syst Stud 9:109-139.

42. Miyata T (1993) Liquid wastes chemistry, UNDP/IAEA/RCA regional training course on radiation technology for environmental conservation, JAERI.

Page $12 / 18$ 
43. Mollah MZI, Khan MA, Khan RA (2009) Effect of gamma irradiated sodium alginate on red amaranth (Amaranthus cruentus $L$.) as growth promoter. Radiat Phys Chem 78(1):61-64. http://dx.doi.org/10.1016/j.radphyschem.2008.08.002

44. Mulvaney RL (1996) Nitrogen-inorganic forms. Methods of soil analysis, part 3-chemical methods. Soil Science Society of America, Madison, pp 1129-1139.

45. Nickelsen MG, Cooper WJ, Kurucz CN, Waite TD (1992) Removal of benzene and selected alkyl-substituted benzenes from aqueous solution utilizing continuous high-energy electron irradiation. Environ Sci Technol 26(1):144-152. http://dx.doi.org/10.1021/es00025a016

46. Noman M, Batool SA, Chaudhary MN (2013) Economic and employment potential in textile waste management of Faisalabad. Waste Manag Res 31(5):485-493. https://doi.org/10.1177/0734242X12474711

47. Panda GC, Das SK, Guha AK (2009) Jute stick powder as a potential biomass for the removal of congo red and rhodamine B from their aqueous solution. J Hazard Mater 164(1):374-379. https://doi.org/10.1016/j.jhazmat.2008.08.015

48. Parvin F, Ferdaus Z, Tareq SM, Choudhury TR, Islam JMM, Khan MA (2015) Effect of gamma-irradiated textile effluent on plant growth. Int J Recycl Org Waste Agricult 4(1):23-30. https://doi.org/10.1007/s40093-014-0081-z

49. Patricia LA, Nascimento D, Talita CESN, Ramos NSM, Da Silva GR, Camara CA, Silva TMS, Moreira KA, Porto ALF (2013) Antimicrobial and antioxidant activities of Pimenta malagueta (Capsicum frutescens). Afr J Microbiol Res 7(27):3526-3533. https://doi.org/10.5897/AJMR2012.2401

50. Paul J, Rawat K, Sarma K, Sabharwal S (2011) Decoloration and degradation of Reactive Red-120 dye by electron beam irradiation in aqueous solution. Appl Radiat Isotopes 69(7):982-987. http://dx.doi.org/10.1016/j.apradiso.2011.03.009.

51. Rabby F (2011) Radiation induced waste water treatment in textile industry. Bangladesh Textile Today, Dhaka.

52. Ribeiro MCM, Starling MCVM, Leão MMD, De Amorim CC (2017) Textile wastewater reuse after additional treatment by Fenton's reagent. Environ Sci Pollut Res 24:6165-6175. https://doi.org/10.1007/s11356-016-6921-9

53. Rouse RD (1979) Water quality management in pond fish culture. In: Research and development series no. 22, Project: AID/DSAN-G 0039, Auburn University, Alabama.

54. Selambakkannu S, Bakar KA, Ming TT, Sharif J (2011) Effect of gamma and electron beam irradiation on textile wastewater. J Sains Nukl Malays 23(2):67-73.

55. Shore J (2002) Colorants and Auxiliaries. Society of Dyers and Colorists, Hampshire, England.

56. Solpan D, Guven 0 (2002) Decoloration and degradation of some textile dyes by gamma irradiation. Radiat Phys Chem 65(45):549-58. https://doi.org/10.1016/S0969-806X(02)00366-3

57. Solpan D, Güven O, Takács E, Wojnárovits L, Dajka K (2003) High-energy irradiation treatment of aqueous solutions of azo dyes: steady-state gamma radiolysis experiments. Radiat Phys Chem 67(3-4):531-534. https://doi.org/10.1016/S0969-806X(03)00100-2

58. Somasiri W, Ruan W, Xiufen L, Jian C (2006) Decolorization of textile wastewater containing acid dyes in UASB reactor system under mixed anaerobic granular sludge. Electron J Environ Agric Food Chem 5(1):1224-1234.

59. Soumya SL, Nair BR (2012) Antifungal efficacy of Capsicum frutescens L. extracts against some prevalent fungal strains associated with groundnut storage. Int J Agric Technol 8(2):739-750.

60. Soutsas K, Karyannis V, Poulios I, Riga A (2010) Decolorization and degradation of reactive azo dyes via heterogeneous photocatalytic processes. Desalination 250(1):345-350. https://doi.org/10.1016/j.desal.2009.09.054

61. Sumartono A (2008) Degradation of Standard Dyes and Textile Wastewater as a Pollutant Model Using Gamma Radiation. Indo J Chem 34(1):1-20. https://doi.org/10.17146/aij.2008.85

62. Symons JM, McKinney RE, Hassis HH (1960) A procedure for determination of the biological treatability of industrial wastes. J Water Pollut Control Fed 32:841-852. http://www.jstor.org/stable/25034216

63. USEPA (2012) Guidelines for Water Reuse 600/R-12/618; Environmental Protection Agency: Washington, DC, USA.

64. Wang J, Chu L (2016) Irradiation treatment of pharmaceutical and personal care products (PPCPs) in water and wastewater: An overview. Radiat Phys Chem 125:56-64. https://doi.org/10.1016/j.radphyschem.2016.03.012

65. Wang M, Yang R, Wang W, Shen Z, Bian S, Zhu Z (2006) Radiation induced decomposition and decoloration of reactive dyes in the presence of $\mathrm{H}_{2} \mathrm{O}_{2}$. Radiat Phys Chem 75(2):286-291. https://doi.org/10.1016/j.radphyschem.2005.08.012

66. Wojnarovits L, Takacs E (2008) Irradiation treatment of azo dye containing wastewater: An overview. Radiat Phys Chem 77(3):225-244. https://doi.org/10.1016/j.radphyschem.2007.05.003

Page 13/18 
67. Wojnarovits L, Takacs E (2013) Structure dependence of the rate coefficients of hydroxyl radical plus aromatic molecule reaction. Radiat Phys Chem 87:82-87. https://doi.org/10.1016/j.radphyschem.2013.02.036

68. WHO (2006) Guidelines for the Safe Use of Wastewater, Excreta and Greywater; World Health Organization: Geneva, Switzerland.

\section{Figures}

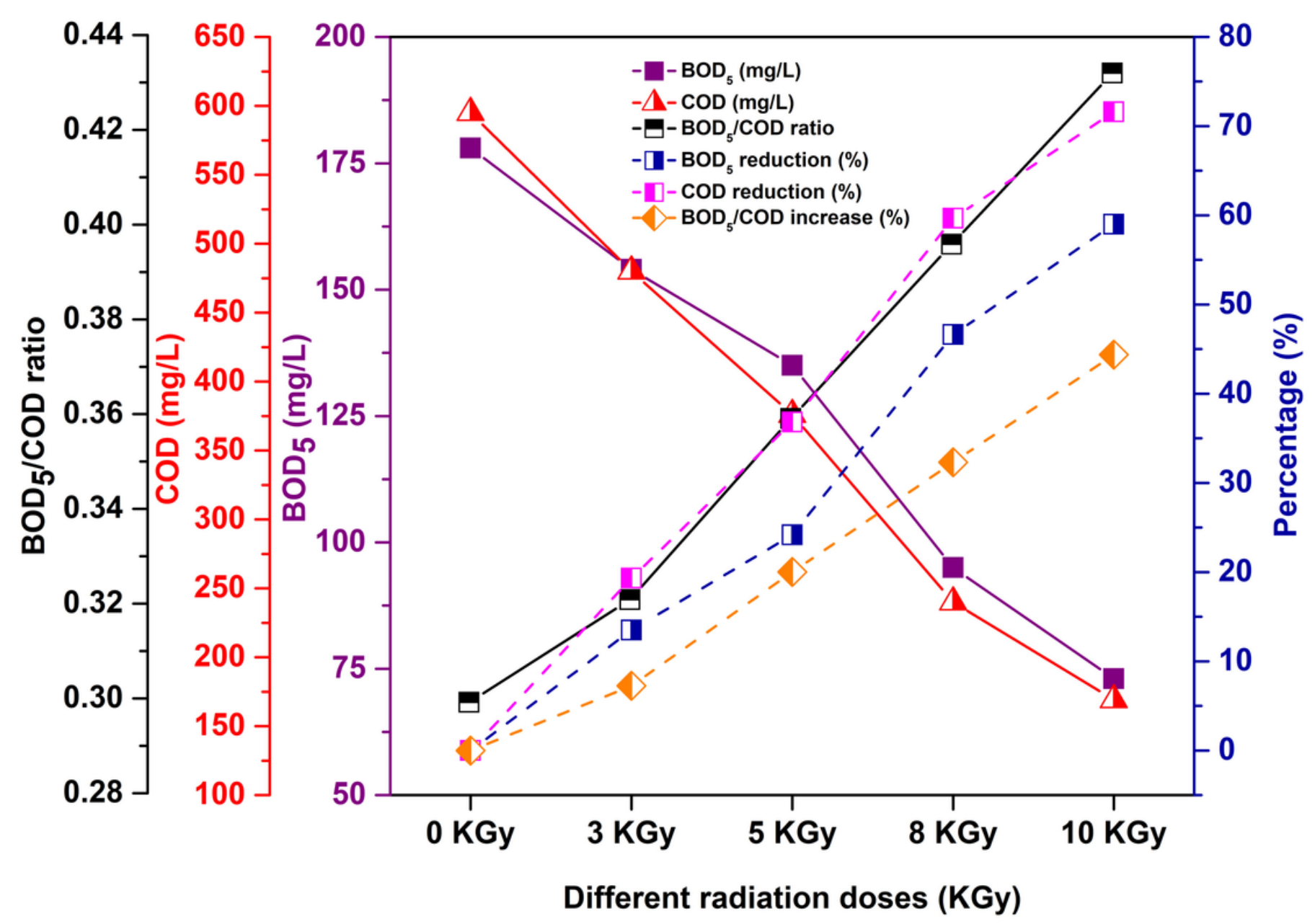

Figure 1

Changes of BOD5, COD and biodegradability index in raw and irradiated textile wastewater. 


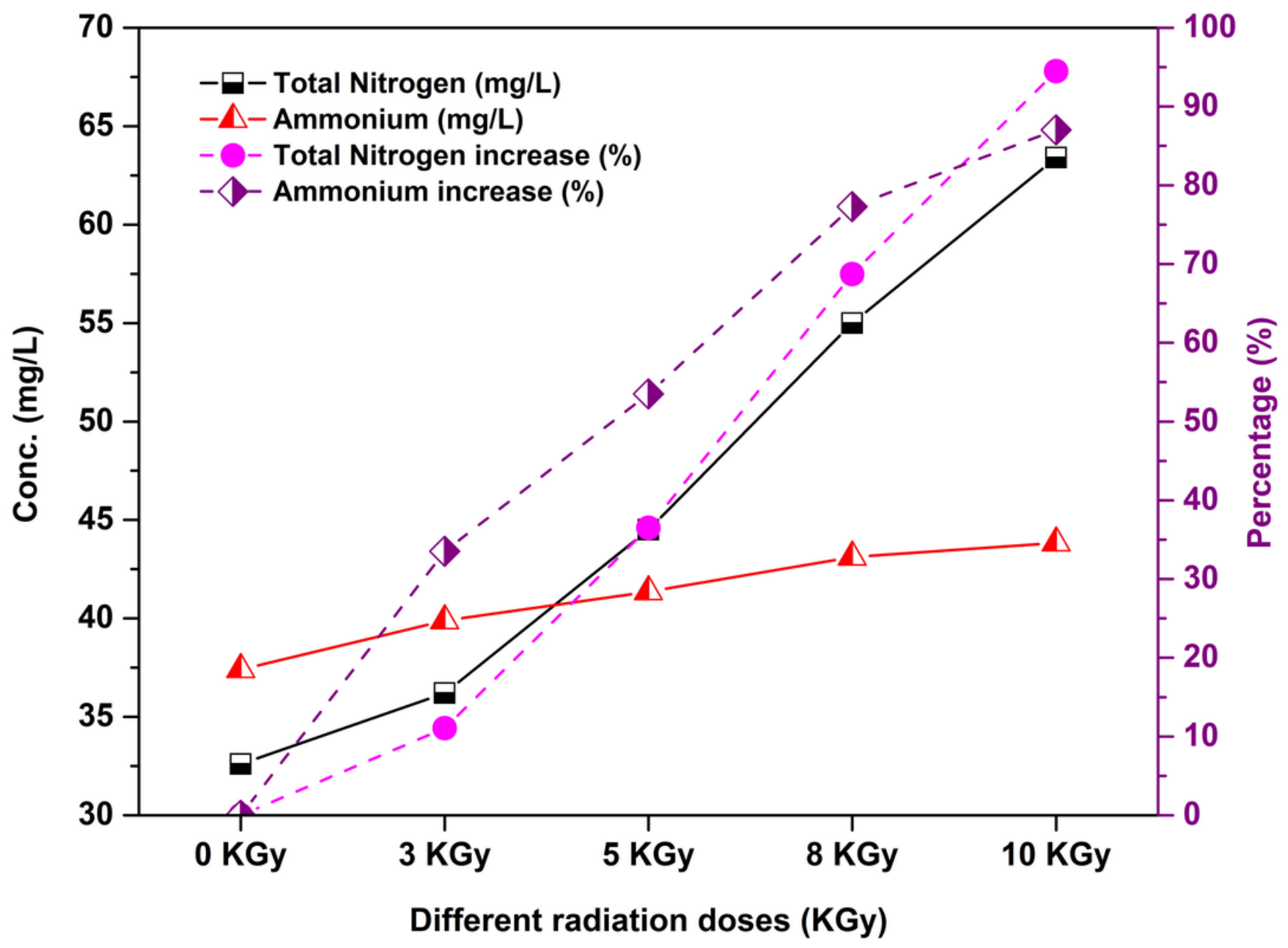

Figure 2

Changes of total nitrogen and ammonium level in raw and irradiated textile wastewater. 


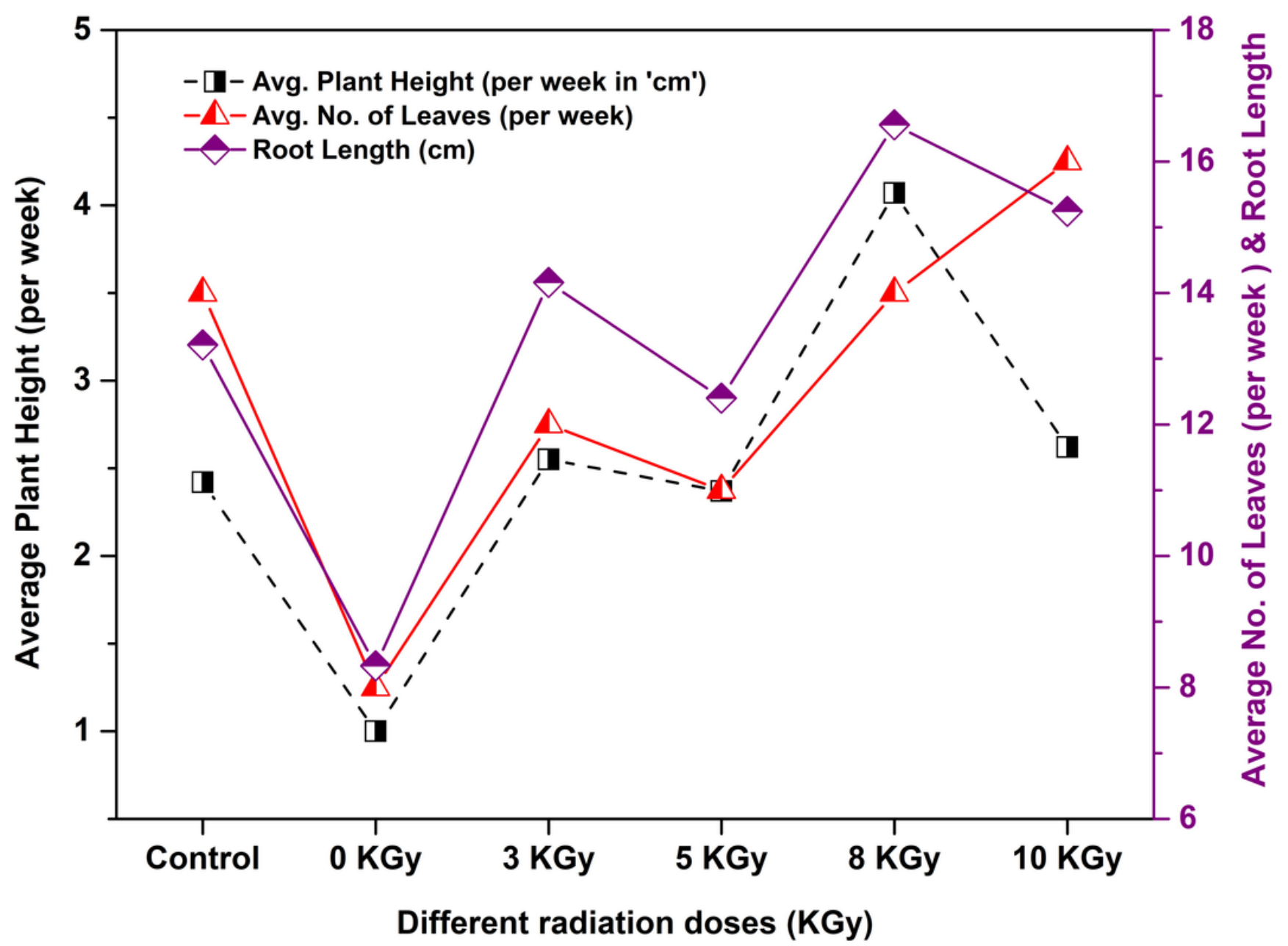

Figure 3

Comparison of average plant height $(\mathrm{cm})$ per week, average number of leaves (per week) and root length for control, unirradiated/raw and gamma ray irradiated Capsicum plants. 


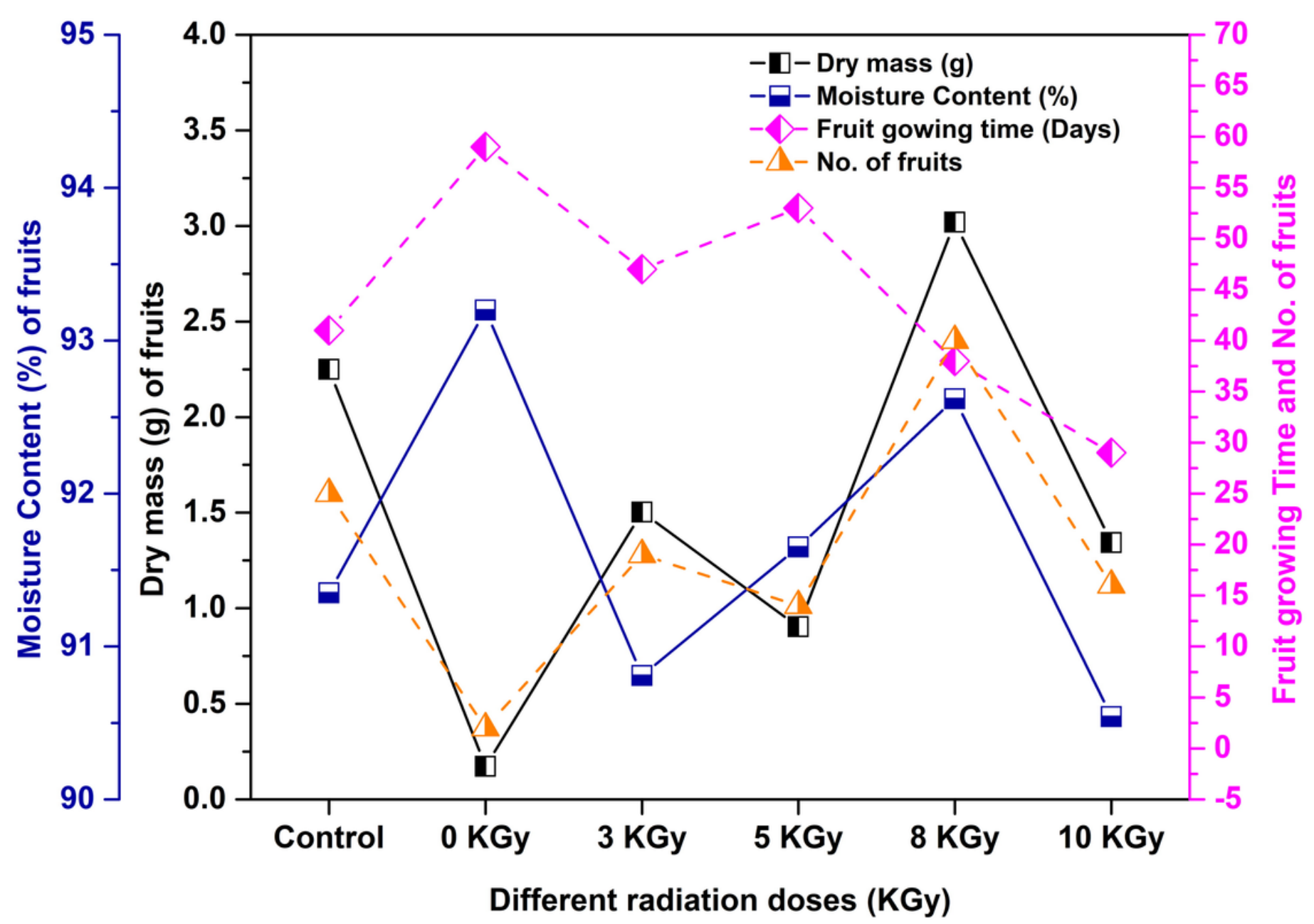

Figure 4

Variation in dry mass, moisture content (\%), fruit growing time and no. of fruits for control, unirradiated/raw and gamma ray irradiated Capsicum plants. 
(a)

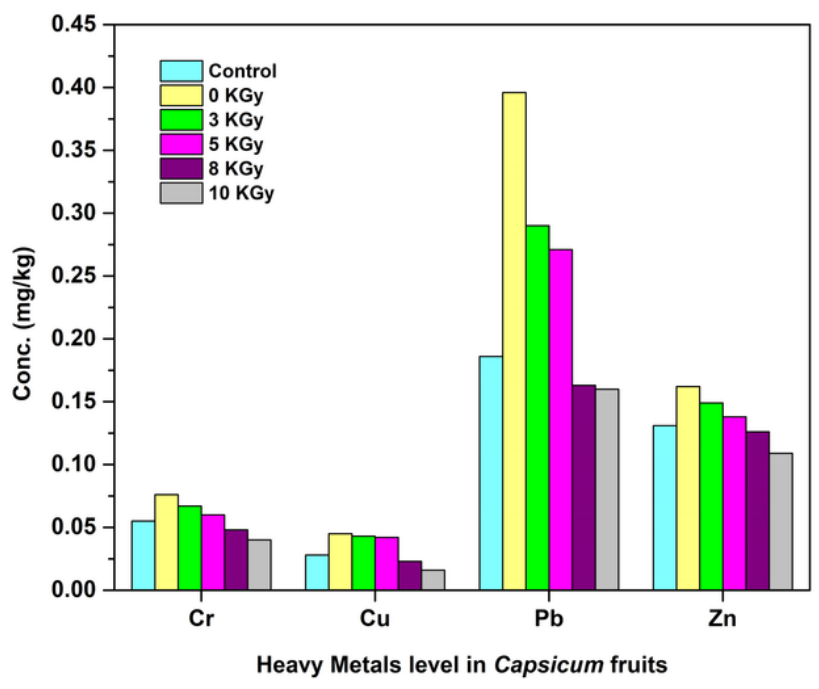

(b)

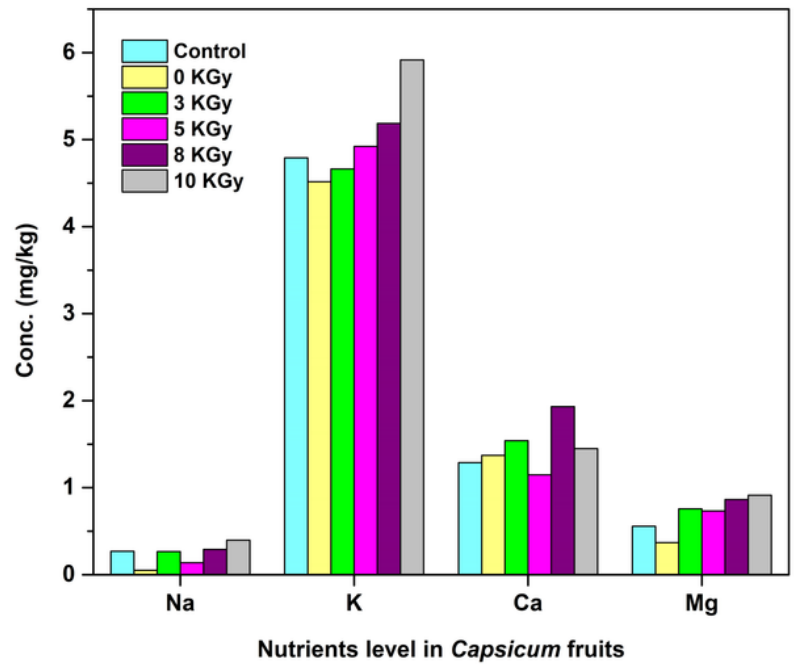

Figure 5

Concentration $(\mathrm{mg} / \mathrm{kg}$ ) of (a) heavy metals and (b) nutrients in Capsicum fruits depending on different irradiation doses.

\section{Supplementary Files}

This is a list of supplementary files associated with this preprint. Click to download.

- SupplementaryData.docx

- GraphicalAbstract.tiff 